\title{
THE EFFECTS OF THE SARBANES-OXLEY ACT OF 2002 ON AUDIT FEES
}

\author{
Sarah B. Cosgrove \\ University of Massachusetts Dartmouth \\ N. Dartmouth, MA \\ M. Scott Niederjohn \\ Lakeland College \\ Sheboygan, WI
}

\begin{abstract}
The Sarbanes-Oxley Act of 2002 was intended to improve corporate governance and increase the transparency of financial audits. The legislation also could have significant effects on the public accounting industry. This study finds evidence of higher audit fees across all firms resulting from compliance with the law. However, after accounting for self-selection of auditors, we do not find evidence that the size of the audit firm affects the magnitude of the audit fee increase.
\end{abstract}

\section{Introduction and Background}

In July of 2002, Congress passed the Sarbanes-Oxley Act (SOX) in response to a wave of corporate governance scandals. This paper will investigate the impact that the SOX Act has had on the audit fees in the public accounting industry and will attempt to determine if that impact differs with the size of the audit firm. This legislation was designed to increase the oversight and regulation of the accounting profession. With the goals of strengthening corporate governance and increasing the transparency of financial audits, the Act aimed to restore public confidence in corporate America following the scandals at Enron, Arthur Andersen, Tyco, WorldCom, Global Crossing, among others. The major provisions of the SOX Act include:

- The establishment of the Public Company Accounting Oversight Board (PCAOB) to set auditing standards.

- A stricter definition of auditor independence that restricts the types of consulting services an auditing firm may provide their clients.

- Stricter criminal penalties for corporate fraud.

- More detailed and timely disclosures of financial information.

Many researchers have noted that the SOX legislation was passed very quickly, perhaps too quickly, and that the law's costs of compliance may exceed its ben- 
efits. Zhang (2005), for example, estimates that the private costs of complying with the SOX Act total \$1.4 trillion. A large proportion of this cost comes from the increased costs of audits in order to comply with the law. Studies have also found that the SOX law has motivated many public firms to go private (or reconsider going public) as a way of avoiding the costs of complying with this law (Hartman, 2005; Block, 2004; Engel, Hayes \& Wang, 2004). One report also raised the concern that foreign firms may be shunning U.S. financial markets to stay clear of this new legislation (Marshall, 2006). The apprehension overseas firms feel toward SOX has been widely reported (Darned Sox, 2006). Recently, a committee, led by former White House economic advisor R. Glenn Hubbard and Goldman Sachs executive John Thornton, was initiated to propose changes to the law and correct the perceived flaws (Sissell, 2006).

SOX legislation was passed at a time when the U.S. public accounting market was becoming increasingly concentrated. In fact, as part of the SOX legislation a United States General Accounting Office (GAO) study was mandated on the public accounting market (GAO, 2003). This study raised the concern that very few audit firms are capable of auditing large U.S. clients and that this problem raises potential choice, price, quality, and concentration risk concerns. The current public accounting market consists of a "Big 4", a middle tier and a lower tier. The Big 4 firms are Deloitte \& Touche, Ernst \& Young, PricewaterhouseCoopers and KPMG. As of the 2003 GAO study, these four firms audited over 78 percent of all U.S. public companies and 99 percent of all public company revenue. Big 4 firms have traditionally dominated the large company audit market due to a number of factors, including the auditors technical skills, reputation and capacity (Doogar, Fargher \& Hong, 2005).

\section{Literature Review and Hypotheses}

The additional work required of an auditor to comply with Sarbanes-Oxley is likely to increase the cost, and therefore, price of audits. This additional work is primarily due to Section 404 of the Act, which requires firms to include an internal control report in their annual report (Rittenberg, Evenson, Martens, 2006). The internal control report must contain "(1) a statement of the responsibility of management for establishing and maintaining an adequate internal control structure and procedures for financial reporting; and (2) an assessment, as of the end of the company's most recent fiscal year, of the effectiveness of the company's internal control structure and procedures for financial reporting." Section 404 also requires the auditor to attest to, and report on, management's assessment. Thus, compliance with this section of the Act imposes both extra work as well as a new risk on the auditor contributing to the higher cost of the audit.

Further, the price of audits could increase due to self-correction of cross-subsidization of services. The Wall Street Joumal postulated that large accounting firms may have been using their auditing services as a loss leader to attract consulting business (Coleman \& Bryan-Low, 2002). According to the U.S. Securities and 
Exchange Commission's (SEC) Final Rule ${ }^{2}$ on auditor independence required by SOX, auditors are prohibited from providing nine categories of services to firms whose external audits they perform. Some of these categories are: bookkeeping services, financial information systems design and implementation, management functions or human resources, and outsourcing of internal audit services. Thus, if auditors were using external auditing services as a loss leader before SOX, this practice would likely be limited or cease post-SOX as they would not have as great an opportunity to recover their auditing costs with fees for consulting and other services.

While articles have discussed an increase in audit fees between 2000 and $2002,{ }^{3}$ no research that we know of has yet shown an increase in audit fees over the time period in which SOX could be tested specifically as the culprit (Asthana, Balsam \& Kim, 2004). This result will be an important starting point for more interesting analysis on the post-SOX industry. Moreover, this study will examine audit fees as well as audit-related fees to attempt to assess the effects of SOX on cross-subsidization of audit services with other services.

\section{Hypothesis 1: The implementation of SOX has increased the costs of corporate audits.}

Of less trivial concern, some question exists as to how SOX might affect the different segments of the U.S. audit market. Research indicates that while the Big 4 firms supply the majority of the market, price competition between auditors in the industry had not been impaired prior to the first SOX compliance deadline (GAO 2003; Chaney, Jeter \& Shivakumar, 2004). That is, while prices for Big 4 audits are higher, in general, the price difference is attributable to quality differences. The middle and small tier accounting firms are price followers and discount compared to the Big 4 to account for differences in breadth and depth of subject matter expertise and proficiency (GAO, 2003). Moreover, Chaney et. al. (2004) found that what was previously identified in the literature as a price premium for the largest tier of auditors disappears when they control for auditee self-selection bias. They base their results on a sample of privately held audit clients in the United Kingdom, thus while their technique is relevant, their results may not be generalizable to the US market for publicly-held firms. However, Ireland and Lennox (2002) find that the premium earned by large audit firms is more than twice as large when selectivity is considered. That is, the authors posit that companies are not randomly assigned to audit firms. Rather, large auditors experience benefits from working with high quality auditees and the data exhibit this selection bias. The present research investigates the premium differences for Big 4 firms and smaller auditors in the post-SOX environment.

Any analysis of the price effects from SOX must consider the segmentation of both the suppliers and the buyers in this industry. As mentioned, the suppliers are split into three segments: Big 4 auditors, middle tier auditors, and small tier auditors. The Big 4 firms are clearly defined as Deloitte \& Touche, Ernst 
\& Young, KPMG, and Pricewaterhouse Coopers. This study defines the middle tier to include all non-Big 4 audit firms with 2004 revenues exceeding $\$ 250$ million, according to Public Accounting Report's Top 100 for 2004. This definition includes: RSM McGladrey (Minneapolis), Grant Thornton (Chicago), BDO Seidman (Chicago) and Crowe Chizek \& Co (Indianapolis). These comprise all non-Big 4 firms with more than 100 SEC clients. All other firms are classified as small tier firms.

Similarly, buyers of audit services divide themselves into segments (Chaney et. al. 2004; Ireland \& Lennox 2002, Simunic \& Stein 1996; Copley, Gaver \& Gaver 1995). For example, it is likely that many very large national and multinational firms will not even consider buying audit services from any non Big 4 firm because their investors require the "brand name" and reputation that a Big 4 audit carries. ${ }^{4}$ While the largest auditees likely have highly inelastic demand for a Big 4 audit, the next tier of auditees, in terms of size and complexity, choose between Big 4 and middle tier auditors for services. As Chaney et. al. (2004) postulate, the largest auditors structure themselves to most efficiently serve their client segment by investing more heavily in technology, training, and facilities than smaller auditors. These investments result in higher fixed costs which smaller clients may find too costly for the marginal benefit of a Big 4 audit. Similarly, small auditees are likely to choose middle tier or small tier auditors whose cost structures are most efficient for the type of audit they require. If the first hypothesis is accurate, SOX influenced the cost structures of auditors of all tiers and, consequently, may lead to changes in auditee's choice of auditor tier.

The different demand elasticities of the buying segments could influence the pricing power of the auditor tiers. Given that the large national or multinational auditees likely have a highly inelastic demand for a Big 4 audit, even if SOX results in higher audit fees, these buyers are unlikely to change their demand for a Big 4 audit. As a result, SOX has likely resulted in Big 4 firms' ability to pass on any additional cost to their largest clients in the form of higher prices. A small portion of Big 4 clients before SOX may switch to middle tier auditors as discussed above in response to significantly higher actual or expected prices; however, most auditees will still have highly inelastic demand and few substitute providers. Therefore, Big 4 auditors will be able to charge higher prices post-SOX.

The middle tier auditor segment may increase pricing power following SOX implementation given the demand elasticities of the buying segments. Consistent with a differentiated market, consumers of the higher quality and higher cost product initially have a more inelastic demand and are willing to pay higher prices. However, as audit fees from all providers hypothetically rise following SOX, auditees' demand becomes more elastic and some of these auditees who previously chose Big 4 auditors may opt for middle tier auditors, increasing the middle tier's residual demand curve and increasing audit fees charged by this tier of audit providers. Indeed, evidence of a recent increase in firms switching to smaller tier auditors is consistent with this idea. Table 1 outlines auditor switches by tier. Specifically, in each of the five years prior to 2003 , fewer than 8 percent 
of auditor switches were from Big 4 to middle tier auditors and fewer than 15 percent of auditor switches were from Big 4 to small tier auditors. However, in $2003,20.6$ percent, or 44 of 214 , auditor switches were from Big 4 auditors to middle tier auditors and 22.9 percent, or 49 of 214 , switches were from Big 4 to small tier auditors. In $2004,29.4$ percent, or 84 of 286 , switches were from Big 4 to middle tier auditors and 31.8 percent, or 91 of 286 , switches were from Big 4 to small tier auditors. While no firms were required to be compliant with SOX until fiscal 2004, the legislation and its requirements were known as of July $2002 .^{5}$ Thus, middle tier auditors may win additional audit clients following SOX as some auditees' demands become more elastic at higher prices.

Table 1

Auditor Switches by Tier

\begin{tabular}{lccccc}
\hline Switch Description & $\begin{array}{c}\text { Total } \\
\text { Switches }\end{array}$ & $\begin{array}{c}\text { Big 4 to } \\
\text { Big 4 }\end{array}$ & $\begin{array}{c}\text { Big 4 to } \\
\text { Middle Tier }\end{array}$ & $\begin{array}{c}\text { Big 4 to } \\
\text { Small Tier }\end{array}$ & Other \\
\hline Mean of Annual Switching & 212.3 & 103 & 11.3 & 22.7 & 75.3 \\
Data for 1998-2001 & & $48.5 \%$ & $5.3 \%$ & $10.7 \%$ & $35.5 \%$ \\
2002 & 753 & 597 & 59 & 61 & 36 \\
& & $79.3 \%$ & $7.8 \%$ & $8.1 \%$ & $4.8 \%$ \\
2002 switches from & 605 & 548 & 31 & 25 & 1 \\
Andersen & & $90.6 \%$ & $5.1 \%$ & $4.1 \%$ & $0.2 \%$ \\
2003 & 214 & 83 & 44 & 49 & 38 \\
& & $38.8 \%$ & $20.6 \%$ & $22.9 \%$ & $17.8 \%$ \\
2004 & 286 & 70 & 84 & 91 & 41 \\
& & $24.5 \%$ & $29.4 \%$ & $31.8 \%$ & $14.3 \%$ \\
\hline
\end{tabular}

* Switches in 2002 are separated to illustrale compulsory switches from Andersen after the firm closed.

In addition to buyers choosing to employ auditors of different tiers, evidence suggests that some auditors play a role in choosing their clients. These supply side effects may disproportionately impact Big 4 and smaller tier audit fees in the post-SOX environment. One study (Doogar et al., 2005) indicated that some Big 4 firms have "fired" their clients in the wake of SOX because the risks or costs of providing audit services are too high. These clients are then forced to choose a different Big 4 provider that also might be unwilling to accept them as a client, or select a smaller tier auditor. Moreover, Big 4 auditors may also shed some audit clients so that they can continue to provide consulting services to these clients without violating independence constraints that are now more strictly enforced. If audit services were loss leaders, as suggested previously, the auditor would prefer to retain the consulting business when forced to choose between providing consulting services or audit services. 
One study also found that many small tier auditing firms have exited the market in order to avoid the costs of registering with the Public Company Accounting Oversight Board ( $\mathrm{PCAOB}$ ), possibly decreasing competition for small audits and raising their prices (Asthana, et al. 2004). Another contends that the PCAOB's one-size-fits-all rules actually create a barrier to entry for small tier auditors (Beckstead, 2006). Even with this decline in supply of small auditors, significantly more competition still exists among auditing firms for small clients. Consider the fact that while only four firms are capable of auditing large multinational firms, more than 1600 firms have registered with the PCAOB as of March of $2006 .{ }^{6}$

Theory supports the idea that both Big 4 and middle tier auditors should be able to increase their pricing power following SOX, but it is unclear whether the proportional increase will differ between these two market segments. If Big 4 auditors are shedding some clients due to the higher risk in serving as their auditor under the new laws and the overall increased workload in the industry or the desire to continue serving them as consultants rather than as auditors, the residual demand curve facing the middle tier auditors would increase by more than the increase in market demand for the Big 4 firms. This larger increase would allow the middle tier auditors to increase their prices proportionately more than Big 4 firms.

Hypothesis 2: Audit fees of the Big 4 and Middle Tier auditors increase more than those of the small Tier; the percent increase in Middle Tier audit fees exceeds the percent increase in Big 4 audit fees.

\section{Data and Sample}

The majority of the data were retrieved from the Compustat database. Cross sectional data from fiscal years 2003 and 2004 for active US companies, excluding American Depository Receipts, were retrieved. ${ }^{7}$ All observations with missing data, observations with the auditor code for unaudited, and firms with only one year of data were deleted leaving 8638 observations. Although the Sarbanes-Oxley Compliance Act became effective July 31, 2002, no firms were required to be compliant with Section 404 until fiscal 2004. As of fiscal 2004, all accelerated filers, ${ }^{8}$ essentially companies with public float of $\$ 75$ million or more who were not eligible to use the small business forms for annual and quarterly reports, were required to comply with Section 404 . To create a binary variable for SOX implementation, the auditors' reports for 2004 were examined. Firms whose auditors conducted audits on internal controls and/or stated that the firm was required to be compliant with SOX Section 404 for fiscal 2004 take a value of one. All other observations take a value of zero.

Audit fees and auditors' reports were retrieved from the Securities and Exchange Commission's Electronic Data Gathering, Analysis, and Retrieval system, EDGAR. Firms are now required to report their annual audit fee data in their 
proxy statements. Due to the manual and time-consuming process of collecting audit fee data, 1000 firms were randomly selected from this sample and audit fee data were collected from EDGAR for these 1000 firms for fiscal year 2003 and 2004. Excluding observations for which no audit fee data were available resulted in 1934 observations.

Although the requirements for reporting audit fees have changed over time, the reporting requirements for the timeframe studied here are consistent. Starting in 2003, firms were required to disclose not only their audit fees, but also audit related fees, tax fees, and all other fees. The SEC's final rule states that the audit fees category should include "fees for services that normally would be provided by the accountant in connection with statutory and regulatory filings or engagements" as well as "fees for services necessary to perform an audit or review in accordance with GAAS" [Generally Accepted Accounting Standards]. ${ }^{9}$ Fees for consulting on internal controls, performing due diligence, tax services, and all other services are excluded from the audit fees variable. The audit-related fees category, created to increase transparency about the auditor/auditee relationship, should include "assurance and related services... that traditionally are performed by the independent accountant." Data on audit fees, audit-related fees as well as their sum are used in this study.

\section{Empirical Methodology}

To test the first hypothesis that audit fees have increased as a result of SOX, an OLS model was used. The model takes the following form:

$$
\begin{aligned}
& \text { Inauditfees }=\beta_{0}+\beta_{1} \text { Inassets }_{i t}+\beta_{2} \text { invrec }_{i t}+\beta_{3} \text { sqrtbus }_{i t}+\beta_{4} \text { sqrtgeo }_{i t} \\
& +\beta_{5} \text { ltdta }_{i t}+\beta_{6} R O A_{i t}+\beta_{7} \text { Y2004 }_{t}+\beta_{8} S O X_{i t}+\varepsilon_{i t}
\end{aligned}
$$

where Inauditfees is the log of audit fees of the $i^{\text {th }}$ firm in the $t^{\text {th }}$ year, Inassets is the log of total assets, invrec is the sum of inventories and receivables divided by total assets, sqrtbus is the square root of the number of business segment areas, sqrtgeo is the square root of the number of geographic segment areas, ltdta is the financial leverage of the firm calculated as long term debt divided by total assets, $R O A$ is the return on assets, $Y 2004$ is a binary variable marking 2004 observations, $S O X$ is a binary variable marking the compliance with SOX legislation, and $\varepsilon$ is the error term. Table 2 displays descriptive statistics for these variables. As stated, audit fee data are available from firm proxy statements. Given the new reporting guidelines, Equation 1 was estimated using the logs of audit fees, audit related fees, and their sum (total audit fees) as dependent variables.

Similar to previous studies of audit fees, variables included in the model control for audit size, complexity, and risk (Menon \& Williams, 2001; Simon \& Francis, 1988; Asthana, et al. 2004). The log of total assets, a well-established determinant of audit fees, provides a control for the size of the audit. The propor- 
tion of inventories and receivables to total assets is included. In the literature, this variable has been used to account for risk and complexity associated with the audit and it addresses specific audit procedures pertaining to inventories and receivables (Menon \& Williams, 2001). The square root of the number of business segments serves as a proxy for the number of subsidiaries. Compustat defines business segments as an industry segment or product line reported by the firm. Presumably, more subsidiaries result in a more complex and, thus, costlier audit. Similarly, the square root of the number of geographic segment areas is included to capture complexity from audits spanning multiple countries. ${ }^{1}$ As an additional measure of the financial condition of the firm, the ratio of long term debt to total assets is included. Finally, return on assets is included as a measure of client profitability and, therefore, risk. ${ }^{2}$ Given that each of these variable measures the size, complexity, and/or risk of the audit, the coefficients are expected to be positive on all of them except for ROA which is expected to be negative. Each of the control variables chosen is supported by Hay, Knechel, and Wong's (2006) meta-analysis on the supply and demand attributes of audit fees.

Table 2

Descriptive Statistics

\begin{tabular}{lcccccc}
\hline Variable & Sample Size & Mean & Median & $\begin{array}{c}\text { Standard } \\
\text { Deviation }\end{array}$ & Minimum & Maximum \\
\hline audit fees & 1934 & $1,078,270$ & 397,500 & $2,339,331$ & 7,300 & $40,900,000$ \\
Inaudit & 1934 & 12.96 & 12.89 & 1.31 & 8.90 & 17,53 \\
audit related fees & 1934 & 169,900 & 27,480 & $591,417.9$ & 0 & $12,500,000$ \\
Inauditrelated & 1431 & 11.03 & 11.00 & 1.58 & 6.55 & 16.34 \\
total audit fees & 1934 & $1,248,170$ & 455,685 & $2,714,951$ & 11,365 & $43,800,000$ \\
Intotaudit & 1934 & 13.08 & 13.03 & 1.33 & 9.34 & 17.60 \\
total assets (in 000s) & 1934 & $2,383.41$ & 237.84 & $11,870.66$ & 1.01 & 315,920 \\
Inassets & 1934 & 5.51 & 5.47 & 2.19 & 0.01 & 12.66 \\
invrec & 1934 & 0.25 & 0.20 & 0.21 & 0.00 & 1.00 \\
sqrtbus & 1934 & 1.40 & 1.00 & 0.48 & 1.00 & 3.16 \\
sqrtgeo & 1934 & 1.57 & 1.41 & 0.44 & 0.00 & 2.24 \\
Itdta & 1934 & 0.18 & 0.10 & 0.29 & 0.00 & 7.96 \\
ROA & 1934 & -7.18 & 2.52 & 47.87 & -1409.22 & 59.59 \\
Y2004 & 1934 & 0.50 & 0.50 & 0.50 & 0.00 & 1.00 \\
SOX & 1934 & 0.22 & 0.00 & 0.42 & 0.00 & 1.00 \\
Big 4 & 1543 & 0.80 & 1.00 & 0.40 & 0.00 & 1.00 \\
\hline
\end{tabular}

The primary variable of interest is the binary variable identifying the impact of SOX. As explained above, the SOX variable takes a value of one for observations in fiscal 2004 if the firm was required to be compliant with the SOX legislation. The coefficient on this variable is expected to be positive reflecting the increase in fees from the legislation. A binary variable for fiscal 
2004 is also included so that a distinction can be made between annual effects and the effects of SOX. ${ }^{13}$

To test the second hypothesis, substantial extensions to the initial model are required. For the purposes of comparison, first a simple OLS model is estimated using Equation 1 with the addition of a binary variable for auditees using Big 4 firms (Big4) to control for the effects of the different tiers of the audit market. Due to an insufficient number of middle tier and small tier observations in the sample, all auditees using non-Big 4 firms remain as the base. In addition, an interaction term between the Big 4 dummy and the SOX variable (SOXbig4) is added so that the total impact of SOX can be explained for each tier. These additions result in the following model:

$$
\begin{aligned}
& \text { Inauditfees }{ }_{i t}=\beta_{0}+\beta_{1} \text { sqrtassets }_{i t}+\beta_{2} \text { invrec }_{i t}+\beta_{3} \text { sqrtbus }_{i t}+\beta_{4} \text { sqrtgeo }_{i t} \\
& +\beta_{5} \text { ltdta }_{i t}+\beta_{6} \text { ROA }_{i t}+\beta_{7} \text { Y2004 }_{t}+\beta_{8} \text { SOX }_{i t}+\beta_{9} \text { Big }_{i t}+\beta_{10} \text { SOXBig }_{i t}+\varepsilon_{i t}
\end{aligned}
$$

However, this is an inappropriate model given that auditees are not randomly assigned to audit firms and that once a firm chooses an auditor, the audit fee they would have been charged by an auditor from the other tier is unobservable. As discussed thoroughly in Ireland and Lennox (2002) and Chaney et al. (2004), ignoring auditor selection effects could lead to biased estimates. Furthermore, Chaney et al. (2004) illustrate the importance of allowing both the intercepts and the slope coefficients to vary across the auditor tier reflecting the differences in investments by the audit firm and the consequent selection by auditees of the most cost-effective auditor given their firm's characteristics, as discussed above. To account for the endogeneity of the choice of audit tier and the truncation of observations, a two-stage selection model is required.

This analysis uses the two-stage Heckman approach outlined by Chaney et al. (2004) with the inclusion of a SOX binary variable to assess the effects of the regulation on auditor tier. The first stage is an auditor choice probit model from which the inverse Mills ratios are calculated and used as an additional explanatory variable in the second stage, an audit fee regression estimated by OLS. The self-selection model is as follows: $\begin{aligned} \text { Probit: } & \text { Big }_{i t}=\beta_{0}+\beta_{1} \text { sqrtassets }_{i t}+\beta_{2} \text { invrec }_{i t}+\beta_{3} \text { sqrtbus }_{i t}+\beta_{4} \text { sqrtgeo }_{i t}+\beta_{5} \text { Itdta }_{i t} \\ & +\beta_{6} \text { ROA }_{i t}+\beta_{7} \text { prevyrBig }^{4}+\varepsilon_{i t}\end{aligned}$

OLS: Inauditfees ${ }_{i t}=\beta_{a 0}+\beta_{a 1}$ sqrtassets $_{i t}+\beta_{a 2}$ invrec $_{i t}+\beta_{a 3}$ sqribus $_{i t}+\beta_{a 4}$ sqrtgeo $_{i t}$ $+\beta_{a s} I t d t a_{i t}+\beta_{a b} R O A_{i t}+\beta_{a 7} Y_{2004}+\beta_{a 8}$ yrenddec $_{i t}+\beta_{a 9} S O X_{i t}+\beta_{a \lambda} \lambda_{a i}+\varepsilon_{i t}$

where the previously defined variables have the same definition and $a$ equals one for firms using Big 4 auditors and zero for firms using non-Big 4 auditors, 
sqrtassets equals the square root of year-end total assets, ${ }^{14}$ prevyrBig4 is a binary variable with a value of one if the firm employed a Big 4 auditor in the previous fiscal year and zero otherwise, yrenddec is a binary variable with a value of one if the firm's fiscal year end occurs in December and zero otherwise.

A brief discussion of the variables in the context of this model is worthwhile. In the probit equation, the expectation on each of the variables except ltdta and $R O A$ is that they will have a positive sign when Big 4 equals one reflecting the relationship between the increased likelihood of choosing a Big 4 auditor the greater the size or complexity of the audit. The expectations on ltdta and $R O A$ are somewhat less predictable. Are high quality or low risk firms more likely to choose (or be accepted as clients by) Big 4 auditors than smaller tier auditors? The results in the literature are mixed (Chaney et al. 2004; Ireland \& Lennox 2002; Hay et al. 2006). On one hand, the higher the risk, the more necessary is a high quality audit. On the other hand, the lower the quality the less likely is a Big 4 firm to accept the auditee as a client, as discussed above. The prevyrBig4 binary variable is included in the probit for identification. While an understandable concern would be that this variable would dominate the equation, the pseudo $\mathrm{R}^{2}$ with this variable included is 0.65 so this does not appear to be a problem.

In the OLS equation, the expectations on the previously defined variables remain consistent but expectations need to be stated for the new terms. First, the self-selection model can only be estimated if the probit and OLS equations have elements that are not common to satisfy the identification condition. The prevyrBig4 variable identifies the probit and additional variables are required to identify Equation 4. Consistent with prior research, the binary yrenddec variable is included to control for peak period pricing. Because most firms end their fiscal years on December 31, substantially more work must be completed in the following months compared to other months throughout the year, which may lead to a price premium. In addition, the year dummy for 2004 and the SOX variable are included in the audit fee equation to account for higher audit fees in 2004 and in SOX compliant firms. The coefficients $\beta_{\lambda 0}$ and $\beta_{\lambda 1}$ in the OLS regression are the inverse Mills ratios from the probit equation. Table 3 contains descriptive statistics for these variables by auditor tier as well as univariate tests for differences between auditees using Big 4 and non-Big 4 auditors. 
Table 3

Descriptive Statistics by Auditor Tier

\begin{tabular}{lcccc}
\hline & \multicolumn{2}{c}{$\begin{array}{c}\text { Big 4 } \\
1543\end{array}$} & \multicolumn{2}{c}{$\begin{array}{c}\text { Non Big 4 } \\
391\end{array}$} \\
\hline Number of Obs. & Mean & Median & Mean & Median \\
\hline Lnaudit & $13.285^{*}$ & $13.200^{*}$ & 11.653 & 11.580 \\
Totassets & $2955.880^{*}$ & $420.580^{*}$ & 124.251 & 22.090 \\
Invrec & $0.235^{*}$ & $0.190^{*}$ & 0.305 & 0.240 \\
Sqrtbus & $1.427^{*}$ & $1.000^{*}$ & 1.287 & 1.000 \\
Sqrtgeo & $1.605^{*}$ & $1.410^{*}$ & 1.458 & 1.410 \\
Ltdta & 0.181 & $0.116^{*}$ & 0.176 & 0.049 \\
ROA & $-3.454^{*}$ & $3.234^{*}$ & -21.897 & -2.311 \\
Yrenddec & 0.732 & 1.000 & 0.714 & 1.000 \\
y2004 & $0.487^{*}$ & $0.000^{* *}$ & 0.550 & 1.000 \\
SOX & $0.261^{*}$ & $0.000^{*}$ & 0.077 & 0.000 \\
\hline
\end{tabular}

* Denotes significance at the $1 \%$ level

** Denotes significance at the $5 \%$ level

\section{Results}

The estimation of the first equation supports the first hypothesis. Complete results are available in Table 4 . While the model appears to be a reasonably good fit for audit fees and total audit fees, with $\mathrm{R}^{2}$ values similar to other studies, the model is not a good fit for audit-related fees. More discussion on this will follow. As expected, the coefficients on the log of assets, the ratio of inventories and receivables to total assets, the square root of business segments, and the square root of geographic segments are all positive and significant for the audit fees equation. These results are consistent with expectations that firms with larger or more complex audits incur higher audit fees. Also as expected, the coefficient on ROA is negative and significant reflecting that firms of higher profitability and thus lower risk face lower audit fees. Interestingly, the ratio of long total debt to total assets has a negative effect on audit fees. Perhaps this result signifies that Big 4 auditors choose not to serve some higher risk customers. Thus, these auditees must use smaller auditors who also tend to charge lower average fees. This question will be re-examined with the second model where auditor tier information is included. The binary variable for 2004 is positive and significant for audit fees and the sum of audit and audit-related fees. This result may be due to increased litigation risk in the wake of SOX. Another possible explanation is the increased preparatory work some firms are doing in anticipation of their compliance deadline with SOX in the near future. ${ }^{15}$ 


\section{Table 4}

Estimation of Equation 1

\begin{tabular}{lccc}
\hline Parameter & $\begin{array}{c}\text { In auditfees } \\
\text { (standard errors) }\end{array}$ & $\begin{array}{c}\text { In auditrelatedfees } \\
\text { (standard errors) }\end{array}$ & $\begin{array}{c}\text { In allaudiffees } \\
\text { (standard errors) }\end{array}$ \\
\hline In assets & $0.4345^{*}$ & $0.4541^{*}$ & $0.4496^{*}$ \\
Invrec & $(0.0091)$ & $(0.0190)$ & $(0.0091)$ \\
& $0.2296^{* *}$ & -0.0210 & $0.2244^{* *}$ \\
Sqrtbus & $(0.0801)$ & $(0.1737)$ & $(0.0806)$ \\
& $0.1770^{*}$ & $0.2115^{*}$ & $0.1762^{*}$ \\
Sqrtgeo & $(0.0356)$ & $(0.0705)$ & $(0.0358)$ \\
& $0.4090^{*}$ & $0.2329^{*}$ & $0.4146^{*}$ \\
Ltdta & $(0.0379)$ & $(0.0764)$ & $(0.0381)$ \\
& $-0.1154^{* *}$ & 0.0603 & -0.0864 \\
ROA & $(0.0590)$ & $(0.1147)$ & $(0.0593)$ \\
& $-0.0028^{*}$ & $-0.0021^{*}$ & $-0.0029^{*}$ \\
Y2004 & $(0.0004)$ & $(0.0007)$ & $(0.0004)$ \\
& $0.2017^{*}$ & 0.0494 & $0.1863^{*}$ \\
SOX & $(0.0384)$ & $(0.0823)$ & $(0.0386)$ \\
& $0.5113^{*}$ & -0.0903 & $0.4519^{*}$ \\
Constant & $(0.0487)$ & $(0.0984)$ & $(0.0490)$ \\
& $9.3966^{*}$ & $7.589^{*}$ & $9.4510^{*}$ \\
$R^{2}$ & $(0.0775)$ & $(0.1666)$ & $(0.0779)$ \\
Adj $R^{2}$ & 0.7170 & 0.3904 & 0.7215 \\
\hline
\end{tabular}

* Denotes significance at the $1 \%$ level,

** Denotes significance at the $5 \%$ level.

*** Denotes significance at the $10 \%$ level.

Most importantly, it is clear that SOX has had a highly significant positive effect on audit fees. Given the semilog model, the coefficient is the partial elasticity. Thus, audit fees are approximately 51 percent higher after SOX than before. This result is consistent with the a priori expectation presented in the first hypothesis.

With regard to the audit-related fees model, some of the results are not surprising. For example, the ratio of inventories and receivables to total assets is not significant in the audit-related fees equation, but this variable was included because inventories and receivables require special treatment during an audit. Thus, insignificance is actually the expected result. The bigger issue with this model is the documented confusion of auditors in the classification of services into the new fee categories. Skantz and Dickins (2005) surveyed auditors regularly responsible for preparing fee disclosures and asked them to classify 25 
different services under the new rules. They found that "fourteen of the services were classified consistently less than 75 percent of the time," In sum, evidence suggests that much confusion surrounds the classification of services, making the audit-related fees category an unreliable dependent variable for the years included in this dataset. As a result, for the second hypothesis, only audit fees will be considered as the estimation of audit related fees provides very little useful information and likely reflects different interpretations of which services should be included in this category.

Complete results of the estimation of the Equation 2 are available in Table 5. This equation is presented strictly for comparison to the more appropriate selection model. As expected, the Big 4 coefficient is positive and significant, indicating that Big 4 auditors charge higher audit fees than smaller tier audit firms. According to this model ( $\mathrm{Eq} 2)$, the marginal effect on audit fees of using a Big 4 auditor after the implementation of $\mathrm{SOX}$ is given by:

$$
\frac{\delta \mathrm{E}[\text { audit fees } \mid S O X, B i g 4]}{\delta S O X}+\beta_{8}+\beta_{10} B i g 4_{i t}
$$

Thus, the marginal effect of SOX on audit fees when a Big 4 auditor is used is 0.6798 with a standard error of 0.0555 , which is significant at the $1 \%$ level. This model suggests that the marginal effect of SOX on audit fees when a smaller tier auditor is used is 0.8249 . A Wald test on the marginal effects confirms that these coefficients are not significantly different from each other. However, given the self-selection bias, these results may not accurately characterize the marginal effects of SOX.

Table 5

Estimation of Equation 2

\begin{tabular}{lcc}
\hline Parameter & In auditfees & Standard Error \\
\hline Sqrtassets & $0.0140^{*}$ & 0.0005 \\
Invrec & $0.2242^{* *}$ & 0.0900 \\
Sqrtbus & $0.3080^{*}$ & 0.0397 \\
Sqrtgeo & $0.5546^{*}$ & 0.0418 \\
Ltdta & $0.3615^{*}$ & 0.0642 \\
ROA & 0.0002 & 0.0004 \\
y2004 & $0.1996^{*}$ & 0.0431 \\
SOX & $0.8249^{*}$ & 0.1512 \\
Big 4 & $1.0382^{*}$ & 0.0502 \\
SOXBig 4 & -0.1451 & 0.1560 \\
Constant & $10.0482^{*}$ & 0.0913 \\
\hline
\end{tabular}

* Denotes significance at the $1 \%$ level.

** Denotes significance at the $5 \%$ level.

$R^{2}=0.6488 \quad A d j R^{2}=0.6470$ 
Table 6 shows the results of the estimation of the auditor choice probit equation. As expected, larger firms (sqrtassets) and firms with more geographic segments are more likely to employ Big 4 auditors. The number of business segments is not a significant driver in choosing between Big 4 and smaller tier auditors. The coefficients on $R O A$, though insignificant, and ltdta are consistent with higher quality and lower risk firms having a greater likelihood of using Big 4 auditors. While the signs on these variables were not known a priori, their outcomes are reasonable and in line with previous research and the popular press (Ireland \& Lennox 2002; Coleman \& Bryan-Low 2002). The sign on invrec is somewhat surprising because the literature suggests that firms with more complex audits prefer Big 4 firms; however, this result is consistent with the descriptive statistics for the sample used here. Using the output from the probit and assuming that if the probability of choosing a Big 4 auditor exceeds 50 percent, then the firm will choose a Big 4 auditor, observations are correctly classified 94.6 percent of the time.

\section{Table 6}

Estimation of Equation 3 Auditor Choice Model

\begin{tabular}{lcc}
\hline Parameter & Big 4 & Standard Error \\
\hline Sqrtassets & $0.0458^{*}$ & 0.0055 \\
Invrec & $-0.7136^{*}$ & 0.2532 \\
Sqrtbus & 0.0138 & 0.1331 \\
Sqrtgeo & -0.0989 & 0.1257 \\
Lidta & $-0.6233^{*}$ & 0.2068 \\
ROA & 0.0011 & 0.0015 \\
prevyrBig4 & $2.9899^{*}$ & 0.1405 \\
Constant & $-1.6764^{*}$ & 0.2772 \\
\hline
\end{tabular}

* Denotes significance at the $1 \%$ level.

** Denotes significance at the $5 \%$ level.

*** Denotes significant at the $10 \%$ level.

$\%$ correctly classified: 94.6

$\%$ using Big $4: 79.8$

The audit fee regression results, correcting for self-selection, are presented in Table 7. Equation 4 is estimated separately for Big 4 and non-Big4 auditees to allow the slope coefficients to vary across the groups, per Chaney et al. (2004). In addition, the inverse Mill's ratio from the first stage $\left(\lambda_{0 i}\right.$ or $\left.\lambda_{\mathrm{i} i}\right)$ is included in this stage to control for self-selection bias. The significance of the coefficients on the lambda terms indicates the self-selection bias. The control variables all take expected signs and are significant, except for $R O A$ and yrenddec which have unexpected signs but are insignificant. The coefficient on the variable of 
primary interest, SOX, is positive and significant for both Big 4 and non-Big 4 firms, though the magnitude is larger for the Big 4 firms.

Table 7

Estimation of Equation 4 Audit Fee Model Adjusting for Selection Bias

\begin{tabular}{|c|c|c|c|c|}
\hline \multirow[t]{2}{*}{ Number of Obs. } & \multicolumn{2}{|c|}{$\begin{array}{l}\text { Big } 4 \\
1543\end{array}$} & \multicolumn{2}{|c|}{$\begin{array}{c}\text { Non Big } 4 \\
391\end{array}$} \\
\hline & In auditfees & Std. Error & In auditfees & Std. Error \\
\hline Sqrtassets & $0.0127^{\star}$ & 0.0005 & $0.0421^{*}$ & 0.0049 \\
\hline Invrec & $0.2217^{\star}$ & 0.1134 & $0.4594^{*}$ & 0.1527 \\
\hline Sqrtbus & $0.3230^{*}$ & 0.0449 & $0.1522^{* *}$ & 0.0917 \\
\hline Sqritgeo & $0.5680^{*}$ & 0.0476 & $0.4482^{*}$ & 0.0935 \\
\hline Ltdta & $0.4799^{*}$ & 0.0926 & $0.1907^{\star \star}$ & 0.0869 \\
\hline ROA & -0.0009 & 0.0008 & -0.0004 & 0.0005 \\
\hline yrenddec & -0.0095 & 0.0499 & -0.0608 & 0.0838 \\
\hline y2004 & $0.1797^{*}$ & 0.0511 & $0.2905^{*}$ & 0.0745 \\
\hline SOX & $0.6645^{\star}$ & 0.0641 & $0.4919^{*}$ & 0.1515 \\
\hline constant & $11.1612^{*}$ & 0.1091 & $10.1212^{\star}$ & 0.1907 \\
\hline lambda & $-0.6948^{*}$ & 0.0869 & $0.1015^{\star \star \star}$ & 0.0548 \\
\hline
\end{tabular}

* Denotes significance at the $1 \%$ level

** Denotes significance at the $5 \%$ level

***Denotes significance at the $10 \%$ level.

The next task is to examine the effects of SOX on audit fees by tier of auditor, using the results of the model corrected for self-selection. First, to determine whether the increase in audit fees is significantly different before and after SOX for each tier, the estimated coefficients are used to predict Inauditfees for all auditees in the sample that were required to be compliant with SOX in 2004. Ttests are performed comparing the predicted Big 4 audit fees pre and post-SOX. The mean and median predicted audit fees for Big 4 auditees pre-SOX were $\$ 859,055$ and $\$ 507,545$, respectively and the mean and median predicted audit fees for Big 4 auditees post-SOX were $\$ 2,096,126$ and $\$ 1,188,776$, respectively. The post-SOX fees for Big 4 auditees are significantly higher with a t-value of 5.61. Likewise, for the non-Big 4 auditees, the mean and median predicted audit fees pre-SOX were $\$ 198,180$ and $\$ 107,751$, respectively, and the mean and median predicted audit fees post-SOX were $\$ 611,466$ and $\$ 256,872$. As with Big 4 auditees, the post-SOX fees for non-Big 4 auditees are significantly higher with a t-value of 2.26 .

Finally, predicted values are compared to determine whether SOX affected Big 4 audit fees differently than non-Big 4 audit fees. Specifically, the percent change in predicted audit fees between 2003 and 2004 are calculated for all firms 
that were required to be compliant with SOX in 2004. These percent changes are then tested to see if they are statistically different across auditor tier. The mean and median predicted audit fee percent increases for SOX compliant firms using Big 4 auditors are 1.482 and 1.371 , respectively, and the mean and median predicted audit fee percent increases for SOX compliant firms using non-Big 4 auditors are 1.581 and 1.248. While the average percent increase in predicted audit fees is larger for non-Big 4 auditees, the percent increases in Big 4 audit fees and non-Big 4 audit fees from SOX are not statistically different.

The results of this analysis are not strong enough to uphold the second stated hypothesis of this paper. However, it is plausible that a longer timeframe of analysis is required to determine how this market is truly changing after the advent of SOX legislation. Furthermore, these results should be interpreted cautiously because the post-SOX audit fee data are only from accelerated filers. These filers are larger firms which would be more likely to use a big 4 auditor and have an inelastic demand for a big 4 audit.

\section{Conclusion}

In the recently burgeoning world of corporate governance, questions about the costly impact of regulatory reactions require answers. Moreover, in the public accounting industry, where market concentration and the ability of firms to exert monopoly power are issues of concern, any regulatory action that could alter or enhance market concentration is worthy of examination in this light. This study sheds light on the magnitude of audit fee increases in the first year of compliance with SOX and examines whether the different segments of the audit market displayed different degrees of pricing power.

As the first study to empirically test audit fees affected by SOX, the results indicate that audit fees were approximately 51 percent higher in the first year of compliance with SOX across the entire spectrum of accounting firms. This study also contributes to the existing literature in the field with its assessment of audit-related fees and the potential effects of SOX on audit-related fees. Unfortunately, the audit-related fees variable is a poor dependent variable given documented auditor confusion on what categories of services should be included in this category.

In addition to an analysis across all accounting firms, this research is the first to attempt to parse out any differences in the way audit fees changed by tier of auditor in the post-SOX environment. The self-selection model employed confirms that auditors are not randomly assigned to auditees, consistent with existing literature in the field. Moreover, after controlling for this self-selection bias, the model illustrates that audit fees for both Big 4 and non-Big 4 auditees were higher following the implementation of SOX and the increases were statistically significant. While the average percent increase in predicted audit fees is larger for non-Big 4 auditees than for Big 4 auditees, suggesting that non-Big 4 auditees may have gained some pricing power following SOX, the changes in 
audit fees are not statistically different between Big 4 auditors and non-Big 4 auditors after the implementation of SOX. This result is interpreted with caution due to the limitations of the post-SOX data that are available.

Several areas for future research stem from this work. First, as audit fee data for non-accelerated filers required to comply with SOX become available, the question of the effects of SOX on pricing power by tier of auditor should be re-examined. The addition to the dataset of more small firms that may have a greater price elasticity could influence the outcome. Another area for future research is the recent increase in auditees switching auditors and the shift of more firms to middle and small tier auditors from Big 4 auditors. Given the timing of the increase in switches, one must question whether SOX has played a role in the number and types of these switches. Moreover, if audit fees are increasing regardless of auditor tier and are not significantly higher for one tier or another, the question remains why would firms opt to switch auditors? Finally, interesting questions remain regarding the extent to which audit firms cross-subsidized between audits and consulting services and what changes, if any, occurred in the joint pricing of those services in the wake of SOX.

\section{References}

Asthana, S., S. Balsam, \& S. Kim. (2004). The effect of Enron, Andersen and SarbanesOxley on the market for audit services. Working paper. Rutgers University. June 2004.

Beckstead, B. (2006). Sarbanes-Oxley: The impact on smaller firms. Accounting Today, $20(16), 6-9$.

Block, S. (2004). The latest movement to going private: An empirical study. Journal of Applied Finance, 14(1), 36-44.

Bureau of Labor Statistics. Producer Price Index Industry Data. Series ID: PCU5412115412114. Retrieved February 2007, from http://data.bls.gov.

Chaney, P., Jeter, D., \& Shivakumar, L. (2004). Self-selection of auditors and audit pricing in private firms. The Accounting Review, 79(1), 51-72.

Coleman C., \& Bryan-Low, C. (2002). Audit fees rise, and investors may pay price. The Wall Street Journal August 12: C1.

Copley, P., Gaver, J., \& Gaver, K. (1995). Simultaneous estimation of the supply and demand of differentiated audits: Evidence from the municipal audit market. Journal of Accounting Research, 33(1), 137-155.

Darned Sox. (2006). The Economist, 380(8495), 84. 
Davidson III, W., Jiraporn, P., \& DaDalt, P. (2006). Causes and consequences of audit shopping: An analysis of auditor opinions, earnings management, and auditor changes. Quarterly Joumal of Business and Economics, 45(1-2), 69-87.

Doogar, R., \& Easley, R. (1998). Concentration without differentiation: A new look at the determinants of audit market concentration. Journal of Accounting and Economics, $25,235-253$.

Doogar, R., Fargher, N., \& Hong, K. (2005). Leveling the playing field, or crumbs from the table? The contestability of the audit market to middle tier firms. Working paper. University of Illinois. May 2005.

Engel, E., Hayes, R. M., \& Wang, X. (2004). The Sarbanes-Oxley Act and firms' going private decisions. Working paper. University of Chicago. May 2004.

Frances, J., \& Simon, D. (1987). A test of audit pricing in the small-client segment of the U.S. audit market. The Accounting Review, l, 145-157.

Government Accounting Office (GAO) (2003). Public accounting firms: Mandated study on consolidation and competition. United States General Accounting Office Report to the Senate Committee on Banking, Housing, and Urban Affairs and the House Committee on Financial Services GAO-03-1158.

Hartman, T. (2005). The cost of being public in the era of Sarbanes-Oxley. Foley and Lardner Presentation. June 2005.

Hay, D. C., Knechel, W. R., \& Wong, N. (2006). Audit fees: A meta-analysis of the effect of supply and demand attributes. Contemporary Accounting Research, 23(1), 141-91.

Ireland, J. C., \& Lennox, C. S. (2002). The large audit firm fee premium: A case of selectivity bias? Joumal of Accounting, Auditing and Finance, 17(1), 73-91.

Johnson, C. (2005). Higher audit fees, more accountability; Sarbanes-Oxley, three years later. The Washington Post. July 30, 2005, D01.

Marsha11, J. (2006). Are foreign issuers shunning the U.S.? Financial Executive, 22(8), $25-28$.

Menon, K., \& Williams, D. D. (2001). Long-term trends in audit fees. Auditing: A Journal of Practice and Theory 20(1), 115-136.

Rittenberg, L., Evenson, M., \& Martens, F. (2006) Internal control: No small matter. Internal Auditor, 63(5), 47-51.

Sankaraguruswamy, S., \& Whisenant, S. (2003). An empirical analysis of voluntary supplied client-auditor realignment reasons. Retrieved September 2003, from SSRN http://ssm.com/abstract $=246096$. 
Skantz, T., \& Dickins, D. (2005-2006). Can fee disclosure be trusted? Regulation, 28(4), 46-47.

Simon, D. T. (1997). Additional evidence on the large audit-firm fee premium as an indication of auditor quality. Journal of Applied Business Research, 13(4), 21-29.

Simon, D. T., \& Francis, J. R. (1988). The effects of auditor changes on audit fees: Tests of price cutting and price recovery. The Accounting Review, 63(2), 255-269.

Simunic, D. A. (1980). The pricing of audit services: theory and evidence. Journal of Accounting Research, $18(1), 161-190$.

Simunic, D.A., \& Stein, M. T. (1996). The impact of litigation risk on audit pricing: A review of the economics and the evidence. Auditing: A Journal of Practice and Theory, 15 Supplement, 119-134.

Sissell, K. (2006). Committee to recommend changes to Sarbanes-Oxley Act. Chemical Week, $168(31), 14$.

Taub, S. (2005). Audit fees double due to Sarbox. CFO.com. Retrieved February 11, 2005, from http:/www.cfo.com/article.cfm/3661477?f=search.

Yue, L. (2006). Audit fees for Sarbanes-Oxley compliance keep rising. Crain's Chicago Business. Retrieved June 19, 2006, from http:/www.chicagobusiness.com/cgi-bin/ news.pl?id=21035\&seenlt $=1$.

Zhang, I. (2005). Economic consequences of the Sarbanes-Oxley Act of 2002. Dissertation. University of Rochester. January 2005.

\section{Footnotes}

1 www.sec.gov/rules/proposed/33-8138.htm

2 www.sec.gov/rules/final/33-8183.htm

3 For example see: "Audit Fees for Sarbanes-Oxley Compliance Keep Rising," (Yue, 2006); "Audit Fees Double Due to Sarbox," (Taub, 2005); "Higher Audit Fees, More Accountability; Sarbanes-Oxley, Three Years Later," (Johnson, 2005).

4 Prior to the SOX legislation, evidence on the number of auditees that chose to hire a different Big 4 auditor following the demise of Andersen supports this idea. Using a sample of 3312 US firms for whom data are available from Compustat, 90.6 percent, or 548 of the 605 firms in the sample who used Andersen in 2001, switched to another Big 4 auditor for service in 2002. This result suggests some auditees' strong preference for a Big 4 audit even in light of concerns that may have arisen following the demise of Andersen.

5 These statistics are based on a sample of 3312 US firms for whom data are available in Compustat. Clearly, there are numerous reasons for firms 
to switch auditors (see Davidson, Jiraporn \& DaDolt 2006, Sankaraguruswamy \& Whisenant 2003). These data do not control for any of the reasons for switching auditors and are merely suggestive. The effect of SOX on switching is outside of the scope of this paper and is an area for future research.

6 For more information please see: http//pcaob.com/Registration/index.aspx

7 After excluding ADRs, two firms (4 observations) remained with an SIC code beginning with 60 for financial services. Consistent with other research in the field these firms were also excluded from the dataset (Simunic 1980).

8 Accelerated filers had to meet each of the following criteria as of the end of their fiscal year: "the issuer had an aggregate market value of voting and non-voting common equity held by non-affiliates of the issuer of $\$ 75$ million or more, as of the last business day of the issuer's most recently completed second fiscal quarter; the issuer had been subject to the reporting requirements of Section 13(a) or 15(d) of the Exchange Act [15 U.S.C. $78 \mathrm{~m}$ (a) or $78 \mathrm{o}(\mathrm{d})]$ for a period of at least 12 calendar months; the issuer previously had filed at least one annual report; and the issuer was not eligible to use Forms 10-KSB and 10-QSB [17 CFR 249.310b and 17 CFR $249.308 \mathrm{~b}$ ] for its annual and quarterly reports." www.sec.gov/rules/final/ fr33-8644.pdf. The definition of accelerated filers changed December 27, 2005 to divide the accelerated filers into two groups. This change does not affect the present study. www.sec.gov/rules/final/33-8183.htm, p39-40.

10 www.sec.gov/rules/final/33-8183.htm, p40.

11 This variable was chosen over foreign sales and foreign sales as a percentage of revenue due to a very high number of missing values for these alternate variables. Consistent with prior research (Simon, 1997) square roots of business segments and geographic segments are used over logs of these values because some observations contain zero values for the number of geographic segments. An alternative specification was attempted using logs of these two values with 0.0001 in place of the zero values resulting in very similar estimates.

12 While some prior studies (Simon \& Francis, 1988) have used the auditor's opinion as a measure of risk, the variation in this variable is so minimal that it would not likely measure risk.

13. An alternative specification was also considered using only time series data for accelerated filers, firms required to comply with SOX in fiscal 2004. Since the SOX binary variable is equivalent to a year binary variable in this specification, all values must be adjusted to 2004 levels using a price deflator to attempt to control for other factors in 2004 that affected audit fees. The Bureau of Labor Statistics producer price index for auditing was used with hesitation as it may remove exactly some of the price variation being examined. Results are available in Appendix 1. 
14 This model uses sqriassets rather than Inassets due to a collinearity problem between Big 4 and Inassets in the probit equation. Alternative specifications using Inassets and using total assets rather than sqrtassets were examined. Given the collinearity with Inassets and the linearity of total assets, the presented specification was deemed to be the most appropriate; however, the estimated coefficients on the SOX variable are positive and significant in all specifications.

15 Although fees for consulting on internal controls should not be included in the reported audit fees, many firms directly stated in their proxy statement that they were included.

\section{Appendix 1}

Table 1A

Alternative Specification of Hypothesis 1: Time Series Data of Accelerated Filers Only

\begin{tabular}{lc}
\hline Parameter & $\begin{array}{c}\text { In adj audiffees } \\
\text { (standard errors) }\end{array}$ \\
\hline In adjassets & $0.4368^{*}$ \\
adjinvrec & $(0.0163)$ \\
& $0.3003^{* *}$ \\
sqrtbus & $(0.1495)$ \\
& $0.2091^{*}$ \\
sqrtgeo & $(0.0519)$ \\
& $0.5505^{*}$ \\
adjlttta & $(0.0588)$ \\
& -0.0833 \\
ROA & $(0.1094)$ \\
& $-0.0078^{*}$ \\
SOX & $(0.0015)$ \\
& $0.6837^{*}$ \\
constant & $(0.0496)$ \\
& $9.1152^{*}$ \\
$\mathrm{R}^{2}$ & $(0.1314)$ \\
Adj R & 0.6346 \\
\hline
\end{tabular}


Dr. Sarah B. Cosgrove is Assistant Professor of Economics at University of Massachusetts Dartmouth where she studies the effects of regulation on imperfectly competitive markets and government regulation of transportation.

Dr. M. Scott Niederjohn is the Charlotte and Walter Kohler Assistant Professor of Economics and Business and the Director of the Center for Economic Education at Lakeland College. Dr Niederjohn conducts research in the areas of economic education, labor markets and public policy studies. 